\title{
Double Transplanting of Boro Rice Increased System Productivity of T. Aman-Potato-Boro Cropping Pattern
}

\author{
Amina Khatun $^{1}$, A. H. Khan ${ }^{1}$ and M. A. Saleque ${ }^{2}$ \\ ${ }^{1}$ Rice Farming Systems Division, ${ }^{2}$ Soil Science Division \\ Bangladesh Rice Research Institute, Gazipur 1701, Bangladesh \\ *Corresponding author: amina_brri@yahoo.com
}

Received: 12 November 2007

Accepted: 27 December 2007

\begin{abstract}
Under irrigated condition, double transplanting (DT) of Boro rice in a T. Aman-Potato-Boro cropping pattern may be an alternative option either to reduce the yield loss of late planted Boro rice or to keep it at a minimum level. An experiment was conducted during 2003 - 2006 at Gazipur and Kapasia with three cropping patterns. The patterns were: T. Aman- Boro- Fallow (CP1), T. Aman-Potato- Boro (CP2) and T. Aman- Potato- double transplanted (DT) Boro (CP3). Rice varieties were BRRI dhan44 and BRRI dhan29 for Aman and Boro seasons, respectively; while Diamont was the potato variety. Rice equivalent yields (REY) in CP2 and CP3 were 82 and 109\% higher than that in CP1 at Gazipur, whereas those were 122 and $179 \%$ higher at Kapasia. The increase of REY in CP2 was attributed to higher potato yield and that in CP3 was due to higher yield of potato and Boro rice. Double transplanting of Boro in $\mathrm{CP} 3$ facilitated greater yield of potato and realized almost similar yield of Boro that was obtained in CP1. Economic analysis showed that the gross margin was the highest in CP3 (US\$ 1797 and 2720 at Gazipur and Kapasia, respectively). CP3 may be recommended for medium high lands of Bangladesh and other Asian rice growing countries.
\end{abstract}

Keywords: Boro, double transplantation, cropping pattern and potato

\section{Introduction}

Introduction of a non-rice crop in between two rice crops may help improve land productivity through a desirable shift in wetland soil ecology in one hand and proper utilization of natural resources to increase system productivity on the other. T. Aman (July - November) - Boro (January - May) is a dominant cropping pattern in irrigated medium highlands of Southeast Asian countries like India, Nepal, Bangladesh and Myanmar. Boro, the dry season irrigated rice, is usually transplanted in January with 4045 day- old seedlings and is harvested in May.
On the contrary, T. Aman - the wet-season rice is transplanted during July - August with 25-35 days old seedlings and is harvested in November. The wet-dry transition period between T. Aman harvest and Boro crop establishment may be a suitable niche for a non-rice crop. Short duration high value rabi crops like potato, mustard, edible poded pea can be fitted in this transition period in some areas of Bangladesh (Elahi et al., 2001; Khan et al., 2004).

Potato is an important non-rice crop for Asian farmers because of its rich food value. It contains not only carbohydrate but is also a good source 
of protein, minerals, vitamin $\mathrm{B}$ and vitamin $\mathrm{C}$. System productivity of $\mathrm{T}$. Aman-Potato-Boro was $29 \mathrm{t} /$ ha compared to only $13 \mathrm{t} / \mathrm{ha}$ in that of $\mathrm{T}$. Aman-Boro-Fallow (Khatun et al., 2003). However, inclusion of potato after T. Aman harvest often delays transplantation of Boro rice and causes a considerable yield reduction. Harvesting of potato crop in around 90 days may delay Boro transplanting till February, and that may reduce Boro yield drastically (Roy et al., 2007). Boro yield declines significantly if transplanted after 25 January (Choudhury and Guha, 2000). The quandary of the productivity of potato and Boro rice may be taken care of by double transplanting of Boro rice. Double transplanting (DT) has been practiced for Boro rice in riverside lands of some Asian countriesIndia, Bangladesh and Nepal since long time back. Double transplanting of Boro rice involves growing of seedling in the nursery for 40-45 days, followed by transplanting in an intermediate field with closer spacing of $10 \times 10$ $\mathrm{cm}$ using 10-12 seedlings hill ${ }^{-1}$. After 45 days, tillers from the intermediate field are splitted and transplanted in the main field. In our preliminary study T. Aman - potato - Boro was found prospective when double trasplanting was practiced in Boro (Rashid et al., 2004). Roy et al. (2007) reported good prospects of T. Amanpotato-double transplanted Boro system in India. However, the present study was undertaken to examine the effectiveness of double transplanting of Boro rice on the growth and yield of Boro itself and system productivity of $\mathrm{T}$. Aman-Potato-Boro cropping pattern.

\section{Materials and Methods}

The study was conducted at the Bangladesh Rice Research Institute (BRRI) experimental farm $\left(24^{0} 0^{\prime} \mathrm{N}, 30^{0} 30^{\prime} \mathrm{E}\right)$, Gazipur and in farmers' field at Kapasia, Gazipur $\left(24^{0} 12^{\prime} \mathrm{N}, 90^{\circ} 43^{\prime} \mathrm{E}\right)$ for three years during 2003 - 2006. Experimental fields in both the locations have silt loam texture and free from normal flooding. Three cropping patterns, T. Aman- Boro- Fallow (CP1), T. Aman-Potatoregular Boro (CP2) and T. Aman- Potato- double transplanted (DT) Boro (CP3) were evaluated. The rice varieties were BRRI dhan44 and BRRI dhan29 in T. Aman and Boro season, respectively. The potato variety was Diamont. The seed rate for rice was $30 \mathrm{~kg} \mathrm{ha}^{-1}$ and that for potato was $1500 \mathrm{~kg} \mathrm{ha}^{-1}$. The experiment was laid out in a Randomized Complete Block Design with four replications.

T. Aman rice was transplanted during 15-20 July with 30-day old seedlings at 2-3 seedlings hill ${ }^{-1}$ and harvested during 15-20 November. Potato was planted during 29 November to 5 December with spacing of $45 \times 15 \mathrm{~cm}$ and harvested in $1^{\text {st }}$ week of February for $\mathrm{CP} 2$ and $3^{\text {rd }}$ week of February for CP3. Potato planting after T. Aman harvest was delayed due to shower during second fortnight of November in each year. Boro rice was transplanted during 10-14 January with 4045 day-old seedlings for CP1. The seedling age of Boro rice for CP2 was 70-75 days. In case of CP3, first transplanting was done with 40-day old seedlings during 10-14 January in the separate small intermediate plots maintaining 10 x $10 \mathrm{~cm}$ spacing with $10-12$ seedlings hill $^{-1}$. After harvesting of potato, tillers of first planted Boro rice from intermediate field were taken out at 43-45 days after transplanting (DAT) and were transplanted in the main fields during 26-27 February with $20 \times 15 \mathrm{~cm}$ spacing and at 5-6 seedlings hill ${ }^{-1}$. Tillers of the $1^{\text {st }}$ transplanted rice covered approximately 6 times in the main field of $2^{\text {nd }}$ transplanting.

N-P-K-S-Zn were applied at 80-20-35-11-1.8 kg $\mathrm{ha}^{-1}$ as urea, TSP, MP, Gypsum and Zinc sulphate, respectively for T. Aman, 114-30-125$22-4 \mathrm{~kg} \mathrm{ha}^{-1}$ for potato and 120-26-60-12-4 kg $\mathrm{ha}^{-1}$ for Boro. In case of Boro rice of CP3, for $1^{\text {st }}$ transplanting P, K, S and Zn were 26-60-12-4 kg $\mathrm{ha}^{-1}$ and $47 \mathrm{~kg} \mathrm{~N} \mathrm{ha}^{-1}$ was topdressed at 15-20 days after transplanting (DAT). For $2^{\text {nd }}$ transplanting $\mathrm{P}, \mathrm{K}, \mathrm{S}$ and $\mathrm{Zn}$ were $26-60-12-4 \mathrm{~kg}$ $\mathrm{ha}^{-1}$ and $94 \mathrm{~kg} \mathrm{~N}^{-1}$ was applied with two equal splits as basal and top dressed at 15-20 DAT. All cultural practices were followed properly. Boro rice of $\mathrm{CP} 1, \mathrm{CP} 2$ and $\mathrm{CP} 3$ were harvested during 14-25 May.

Number of tillers, panicles, grains and 1000grain weight were recorded from $1 \mathrm{~m}^{2}$ area samples. Rice yield was recorded from $5 \mathrm{~m}^{2}$ and 
potato from $6 \mathrm{~m}^{2}$ area. The grain yield of rice was expressed in $\mathrm{t} \mathrm{ha}^{-1}$ at $14 \%$ moisture level. The data were analyzed statistically and means were compared by Least Significant Difference Test (Gomez and Gomez, 1983). Total productivity of three cropping systems was compared in terms of rice equivalent yield (REY). The REY was computed by converting yield of potato in to the yield of rice following Singh et al. (1993) as follows:

REY of the crop

$=$ Yield of potato $(\mathrm{kg} / \mathrm{ha}) \times$ Market price of potato $(\mathrm{Tk} / \mathrm{kg})$ Market price of rice $(T k / h a)$

Total variable cost for different cropping systems and local market prices of the products were recorded for economic analysis.

\section{Results and discussion}

\subsection{T. Aman}

ANOVA for grain yield in T. Aman reflected significant main effects of location and year, and the interaction effects of location and year (Table 1). Mean grain yields for the pattern $\mathrm{CP} 1, \mathrm{CP} 2$ and $\mathrm{CP} 3$ at Gazipur were 4.92, 4.99 and $4.90 \mathrm{t} \mathrm{ha}^{-1}$ and that at Kapasia were 5.35, 5.42 and $5.37 \mathrm{t} \mathrm{ha}^{-1}$, respectively. The yield of T. Aman rice was higher at Kapasia than at Gazipur (Table 2). The main effect of $\mathrm{CP}$ and the interaction effect of $\mathrm{CP}$ and location were not significant for grain yield.

\subsection{Potato}

Interaction effect of cropping pattern (CP), location and year for tuber and stover yield were not significant $(\mathrm{P}=0.24)$. However, the interaction effect of $\mathrm{CP}$ and location, location and year for tuber and biomass yield were significant $(\mathrm{P}=0.00)$. The main effect of $\mathrm{CP}$, location and year for both tuber and stover yield was significant $(\mathrm{P}=0.00$, Table 3$)$.

The tuber yield in CP3 was higher than that in $\mathrm{CP} 2$ both at Gazipur and Kapasia, probably due to longer field duration of potato associated with double transplanting of Boro in CP3. Tuber production in 2005 was the highest followed by 2006 and the lowest in 2004 at Gazipur. But at Kapasia, highest tuber production was in 2004 followed by 2006 and the lowest was in 2005
(Table 4). For stover yield, the main effect of CP, location and year, and the interaction effect of location and year, location and $\mathrm{CP}$ were significant. Stover production was the highest in CP2 and the lowest in CP3 at both the locations. Year to year variation in stover production was significant both at Gazipur and Kapasia (Table 5).

\subsection{Boro}

Interaction effects of $\mathrm{CP}$, location and year for grain yield, straw yield, days to flowering and days to maturity were significant $(p=0.04)$. Interaction effect of $\mathrm{CP}$, location and year for number of tillers $/ \mathrm{m}^{2}$, panicles $/ \mathrm{m}^{2}$, grains/panicle and 1000-grain weight were not significant $(\mathrm{P}>0.31)$. The interaction effect of $\mathrm{CP}$ and location for grain yield and straw yield were significant $(\mathrm{P}<0.05)$, though for number of tillers $/ \mathrm{m}^{2}$, panicles $/ \mathrm{m}^{2}$, grains/panicle, 1000grain weight, days to flowering and maturity were not significant $(\mathrm{P}>0.24)$. Interaction effects of location and year for number of tillers $/ \mathrm{m}^{2}$, panicle $/ \mathrm{m}^{2}$, grain yield, straw yield, days to flowering and days to maturity were significant ( $\mathrm{P}<0.007)$, but for grains/panicle and 1000-grain weight were not significant $(\mathrm{P}>0.15)$. Interaction effects of $\mathrm{CP}$ and year for grain yield, straw yield, days to flowering, days to maturity and number of grains/panicle were significant $(\mathrm{P}<0.009)$, but for number of tillers $/ \mathrm{m}^{2}$, panicles $/ \mathrm{m}^{2}$ and 1000-grain weight the effect was not significant $(\mathrm{P}>0.12)$ (Table 6 and Table 7).

Grain yield of Boro in CP1 was the highest followed by CP3 and the lowest in CP2 both at Gazipur and Kapasia. Mean grain yields for the patterns CP1, CP2 and CP3 were 6.49, 5.30 and $5.96 \mathrm{t} / \mathrm{ha}$ at Gazipur and 6.75, 5.62 and $6.51 \mathrm{t} / \mathrm{ha}$ at Kapasia, respectively. The higher yield in CP1 may be attributed due to timely transplanting and optimum seedling age i.e. 40-45 days. Boro yield declines significantly if transplanted after 25 January (Choudhury and Guha, 2000). The highest grain yield was obtained in 2006 at Gazipur. However, at Kapasia, the Boro yield in 2004 was the maximum (Table 8). In CP2, older seedlings (70-72-day old) of Boro rice which delayed establishment probably caused decreased grain yield. 
Table 1. F-Probability values of yield and yield components of T. Aman rice.

\begin{tabular}{|c|c|c|c|c|c|c|c|}
\hline \multirow{2}{*}{$\begin{array}{l}\text { Source of } \\
\text { variation }(\mathrm{SV})\end{array}$} & \multirow[t]{2}{*}{$\mathrm{df}$} & \multicolumn{6}{|c|}{ F-Probability values } \\
\hline & & Tiller $/ \mathrm{m}^{2}$ & $\begin{array}{l}\text { Panicle/ } \\
\mathrm{m}^{2}\end{array}$ & $\begin{array}{l}\text { Grains/pa } \\
\text { nicle }\end{array}$ & 1000-grain wt & $\begin{array}{l}\text { Grain } \\
\text { yield } \\
\text { (t/ha) }\end{array}$ & $\begin{array}{l}\text { Straw } \\
\text { yield } \\
\text { (t/ha) }\end{array}$ \\
\hline Replication (R) & 3 & 0.47 & 0.67 & 0.67 & 0.77 & 0.42 & 0.94 \\
\hline Location (L) & 1 & 0.73 & 0.88 & 0.00 & 0.09 & 0.00 & 0.00 \\
\hline $\mathrm{R} \times \mathrm{L}$ & 3 & 0.67 & 0.89 & 0.00 & 0.44 & 0.29 & 0.46 \\
\hline $\begin{array}{l}\text { Cropping } \\
\text { pattern }(\mathrm{CP})\end{array}$ & 2 & 0.26 & 0.37 & 0.02 & 0.81 & 0.36 & 0.56 \\
\hline Year $(Y)$ & 2 & 0.00 & 0.00 & 0.00 & 0.00 & 0.00 & 0.00 \\
\hline $\mathrm{CP} \times \mathrm{Y}$ & 4 & 0.32 & 0.35 & 0.25 & 0.30 & 0.95 & 0.62 \\
\hline $\mathrm{L} \times$ Year & 2 & 0.01 & 0.08 & 0.00 & 0.03 & 0.00 & 0.00 \\
\hline $\mathrm{CP} \times \mathrm{L}$ & 2 & 0.60 & 0.53 & 0.00 & 0.44 & 0.93 & 0.59 \\
\hline $\mathrm{CP} \times \mathrm{L} \times \mathrm{Y}$ & 4 & 0.83 & 0.93 & 0.12 & 0.17 & 0.93 & 0.89 \\
\hline
\end{tabular}

Table 2. Grain yield (t/ha) of T.Aman rice (BRRI dhan44) in three years at two locations under three cropping patterns.

\begin{tabular}{lcccccccc}
\hline \multirow{2}{*}{$\begin{array}{c}\text { Cropping } \\
\text { pattern }\end{array}$} & \multicolumn{3}{c}{ Gazipur } & \multicolumn{3}{c}{ Kapasia } \\
\cline { 2 - 9 } & 2004 & 2005 & 2006 & Mean for CP & 2004 & 2005 & 2006 & Mean for CP \\
\hline A-F-B & 5.93 & 4.23 & 4.61 & 4.92 & 5.82 & 5.42 & 4.82 & 5.35 \\
A-P-B & 6.04 & 4.25 & 4.68 & 4.99 & 5.93 & 5.54 & 4.80 & 5.42 \\
A-P-DB & 5.88 & 4.19 & 4.64 & 4.90 & 5.83 & 5.51 & 4.77 & 5.37 \\
Mean for year & 5.95 & 4.22 & 4.64 & 4.94 & 5.86 & 5.49 & 4.80 & 5.38 \\
\hline
\end{tabular}

$\mathrm{LSD}_{(0.05)}$ NS (for cropping pattern, CP), 0.90 (Location ), 0.11(Year), NS (CP x Year), 0.16 (Location x Year), NS (Location $\mathrm{x}$ CP), NS (CP x Location $\mathrm{x}$ Year)

Table 3. F-Probability values of tuber and stover yield of potato.

\begin{tabular}{llcc}
\hline Source of variation (SV) & df & \multicolumn{2}{c}{ F-Probability values } \\
\cline { 3 - 4 } & & Tuber yield (t/ha) & stover yield (t/ha) \\
\hline Replication (R) & 3 & 0.21 & 0.22 \\
Location (L) & 1 & 0.00 & 0.00 \\
R $\times$ L & 3 & 0.02 & 0.00 \\
Cropping pattern (CP) & 2 & 0.00 & 0.00 \\
Year (Y) & 2 & 0.00 & 0.00 \\
CP $\times$ Y & 4 & 0.29 & 0.51 \\
L $\times$ Year & 2 & 0.00 & 0.00 \\
CP $\times$ L & 2 & 0.00 & 0.00 \\
CP $\times$ L $\times$ Y & 4 & 0.24 & 0.17 \\
\hline
\end{tabular}


Table 4. Tuber production ( $t / h a)$ of potato (Diamont) in three seasons at two locations under three cropping patterns.

\begin{tabular}{lcccccccc}
\hline \multirow{2}{*}{$\begin{array}{l}\text { Cropping } \\
\text { pattern }\end{array}$} & \multicolumn{4}{c}{ Gazipur } & \multicolumn{3}{c}{ Kapasia } \\
\cline { 2 - 8 } & 2004 & 2005 & 2006 & Mean for CP & 2004 & 2005 & 2006 & Mean for CP \\
\hline A-F-B & - & - & - & - & - & - & - & - \\
A-P-B & 10.25 & 21.13 & 12.11 & 14.50 & 23.03 & 17.55 & 17.58 & 19.39 \\
A-P-DB & 13.88 & 22.25 & 16.72 & 17.62 & 27.83 & 26.25 & 27.08 & 27.05 \\
Mean for year & 12.07 & 21.69 & 14.42 & 16.06 & 25.43 & 21.90 & 22.33 & 23.22 \\
\hline
\end{tabular}

$\operatorname{LSD}_{(0.05)} 1.54$ (for cropping pattern, CP), 1.54 (Location ), 1.88(Year), NS (CP x Year), 2.66 (Location x Year), 2.17 (Location $\mathrm{x}$ CP), NS (CP x Location x Year)

Table 5. Stover production (t/ha) of potato in three seasons at two locations under three cropping patterns.

\begin{tabular}{lcccccccc}
\hline Cropping & \multicolumn{4}{c}{ Gazipur } & \multicolumn{5}{c}{ Kapasia } \\
\cline { 2 - 8 } pattern & 2004 & 2005 & 2006 & Mean for CP & 2004 & 2005 & 2006 & Mean for CP \\
\hline A-F-B & - & - & - & - & - & - & - & - \\
A-P-B & 9.38 & 19.00 & 12.55 & 13.64 & 13.25 & 13.83 & 15.50 & 14.19 \\
A-P-DB & 4.83 & 10.25 & 4.95 & 6.68 & 10.63 & 12.40 & 13.15 & 12.06 \\
Mean for year & 7.11 & 14.63 & 8.75 & 10.16 & 11.94 & 13.12 & 14.33 & 13.13 \\
\hline
\end{tabular}

$\mathrm{LSD}_{(0.05)} 1.18$ (for cropping pattern, CP), 1.18 (Location ), 1.44(Year), NS (CP x Year), 2.04 (Location x Year), 1.66(Location x CP), NS (CP x Location x Year)

Table-6. F- Probability values of yield, yield component of Boro rice and rice equivalent yield.

\begin{tabular}{lcccccccccc}
\hline & & \multicolumn{7}{c}{ F-Probability values } \\
\cline { 2 - 11 } $\begin{array}{c}\text { Source of } \\
\text { variation } \\
\text { (SV) }\end{array}$ & $\mathrm{df}$ & $\begin{array}{c}\text { Tiller/ } \\
\mathrm{m}^{2}\end{array}$ & $\begin{array}{c}\text { Panicl } \\
\mathrm{e} / \mathrm{m}^{2}\end{array}$ & $\begin{array}{c}\text { Grains/ } \\
\text { panicle }\end{array}$ & $\begin{array}{c}1000 \text {-grain } \\
\text { wt }\end{array}$ & $\begin{array}{c}\text { Grain } \\
\text { yield } \\
\text { (t/ha) }\end{array}$ & $\begin{array}{c}\text { Straw } \\
\text { yield } \\
\text { (t/ha) }\end{array}$ & $\begin{array}{c}\text { Days to } \\
\text { flowering } \\
\text { (DF) }\end{array}$ & $\begin{array}{c}\text { Days to } \\
\text { maturity } \\
\text { (DM) }\end{array}$ & $\begin{array}{c}\text { Rice } \\
\text { equivalen } \\
\text { tyield } \\
\text { (t/ha) }\end{array}$ \\
\hline $\begin{array}{l}\text { Replicatio } \\
\mathrm{n}(\mathrm{R})\end{array}$ & 3 & 0.974 & 0.947 & 0.014 & 0.030 & 0.429 & 0.170 & 0.239 & 0.239 & 0.262 \\
\hline Location (L) & 1 & 0.000 & 0.000 & 0.000 & 0.000 & 0.000 & 0.000 & 0.000 & 0.000 & 0.000 \\
\hline $\mathrm{R} \times \mathrm{L}$ & 3 & 0.517 & 0.449 & 0.760 & 0.084 & 0.019 & 0.052 & 0.158 & 0.158 & 0.027 \\
\hline $\begin{array}{l}\text { Cropping } \\
\text { pattern (CP) }\end{array}$ & 2 & 0.000 & 0.000 & 0.000 & 0.701 & 0.000 & 0.000 & 0.000 & 0.000 & 0.000 \\
\hline $\mathrm{Year}(\mathrm{Y})$ & 2 & 0.000 & 0.000 & 0.000 & 0.701 & 0.000 & 0.000 & 0.000 & 0.000 & 0.027 \\
\hline $\mathrm{CP} \times \mathrm{Y}$ & 4 & 0.281 & 0.116 & 0.009 & 0.069 & 0.000 & 0.000 & 0.000 & 0.000 & 0.003 \\
\hline $\mathrm{L} \times \mathrm{Year}$ & 2 & 0.001 & 0.001 & 0.154 & 0.516 & 0.000 & 0.007 & 0.000 & 0.000 & 0.000 \\
\hline $\mathrm{CP} \times \mathrm{L}$ & 2 & 0.871 & 0.442 & 0.573 & 0.235 & 0.010 & 0.054 & 0.483 & 0.599 & 0.000 \\
\hline $\mathrm{CP} \times \mathrm{L} \times \mathrm{Y}$ & 4 & 0.571 & 0.310 & 0.785 & 0.641 & 0.000 & 0.000 & 0.044 & 0.003 & 0.000 \\
\hline
\end{tabular}


Table 7. Grain yield (t/ha) in Boro rice (BRRI dhan29) in three seasons at two locations under three cropping patterns.

\begin{tabular}{lllllllll}
\hline $\begin{array}{l}\text { Cropping } \\
\text { pattern }\end{array}$ & \multicolumn{9}{c}{ Gazipur } \\
\cline { 2 - 9 } & 2004 & 2005 & 2006 & $\begin{array}{l}\text { Mean } \\
\text { for CP }\end{array}$ & 2004 & 2005 & 2006 & $\begin{array}{l}\text { Mean } \\
\text { for CP }\end{array}$ \\
\hline A-F-B & 6.58 & 5.93 & 6.95 & 6.49 & 6.61 & 5.89 & 7.74 & 6.75 \\
A-P-B & 4.83 & 5.43 & 5.64 & 5.30 & 6.36 & 5.45 & 5.04 & 5.62 \\
A-P-DB & 5.66 & 5.89 & 6.32 & 5.96 & 6.72 & 5.98 & 6.84 & 6.51 \\
Mean for & 5.69 & 5.75 & 6.30 & 5.91 & 6.56 & 5.77 & 6.54 & 6.29 \\
\hline
\end{tabular}

$\mathrm{LSD}_{(0.05)} 0.10$ (for cropping pattern, CP), 0.82 (Location ), 0.10(Year), 0.173 (CP x Year), 0.14 (Location x Year), 0.14 (CP x Location), 0.25 (CP x Location x Year)

Table 8. Straw yield (t/ha) in Boro rice (BRRI dhan29) in three seasons at two locations under three cropping patterns.

\begin{tabular}{|c|c|c|c|c|c|c|c|c|}
\hline \multirow{2}{*}{$\begin{array}{l}\text { Cropping } \\
\text { pattern }\end{array}$} & \multicolumn{4}{|c|}{ Gazipur } & \multicolumn{4}{|c|}{ Kapasia } \\
\hline & 2004 & 2005 & 2006 & $\begin{array}{l}\text { Mean } \\
\text { for CP }\end{array}$ & 2004 & 2005 & 2006 & $\begin{array}{l}\text { Mean } \\
\text { for CP }\end{array}$ \\
\hline A-F-B & 7.10 & 6.82 & 7.52 & 7.15 & 7.18 & 6.99 & 7.32 & 7.16 \\
\hline A-P-B & 6.10 & 6.65 & 6.68 & 6.48 & 6.74 & 6.60 & 7.12 & 6.82 \\
\hline A-P-DB & 6.68 & 6.87 & 6.85 & 6.80 & 8.29 & 6.30 & 7.52 & 7.37 \\
\hline $\begin{array}{l}\text { Mean for } \\
\text { year }\end{array}$ & 6.63 & 6.78 & 7.02 & 6.81 & 7.40 & 6.63 & 7.32 & 7.12 \\
\hline
\end{tabular}

Table 9. Days to flowering in Boro rice (BRRI dhan29) in three seasons at two locations under three cropping patterns.

\begin{tabular}{lllllllll}
\hline $\begin{array}{l}\text { Cropping } \\
\text { pattern }\end{array}$ & \multicolumn{3}{c}{ Gazipur } & \multicolumn{3}{c}{ Kapasia } \\
\cline { 2 - 9 } & 2004 & 2005 & 2006 & Mean for CP & 2004 & 2005 & 2006 & Mean for CP \\
A-F-B & 133 & 127 & 125 & 128 & 134 & 133 & 128 & 132 \\
A-P-B & 142 & 139 & 135 & 139 & 141 & 145 & 141 & 142 \\
A-P-DB & 141 & 134 & 127 & 134 & 143 & 138 & 134 & 138 \\
Mean for year & 139 & 133 & 129 & 134 & 139 & 139 & 134 & 137 \\
\hline
\end{tabular}

$\operatorname{LSD}_{(0.05)} 0.82$ (for cropping pattern, CP), 0.67 (Location), 0.82 (Year), 1.42 (CP x Year), 1.16 (Location $\mathrm{x}$ Year), NS (CP x Location), 2.01 (CP x Location $x$ Year) 
Delayed transplanting of Boro rice shortens growing period as reported by Roy et al. (2007). In CP3, although it was delayed establishment, in first transplantation at intermediate field, the crops probably got nourishment from management practices. Choudhury et al. (1995) and Mridha et al. (1991) reported no significant yield reduction due to transplanting of splitted tillers from mother plant.

Significant main effects for $\mathrm{CP}$, location and year, and the interaction effects of CP and year, location and year, $\mathrm{CP}$ and location and year was observed for straw yield (Table 9). At Gazipur, the highest straw yield was obtained from CP1 followed by CP3 and the lowest was in CP2. However, at Kapasia, the highest straw yield was obtained from CP3 which was followed by CP1 (Table 9).

Interaction effect of $\mathrm{CP} \times$ location $\times$ year was significant for days to flowering (DF). At Gazipur, mean DF for CP1 was 128 days which was followed by CP3 (i.e.134 days) and CP2 took the longest duration (139 days). A similar trend was also observed at Kapasia. At Gazipur, mean DF for the interaction effect of CP and year was 134 days, whereas at Kapasia, that was 137 days (Table 10).

Significant main effects of $\mathrm{CP}$, location and year, and the interaction effects of $\mathrm{CP}$ and year, location and year, $\mathrm{CP}$, location and year were observed for days to maturity (DM). Mean DM in CP1 was 158 days followed by $\mathrm{CP} 3$ (i.e. 165 days) and the pattern CP2 took the highest DM (i.e. 170 days). A similar trend was also observed at Kapasia (Table 11).
Interaction effect of $\mathrm{CP} \times$ location $\times$ year for rice equivalent yield (REY) was significant $(\mathrm{p}=$ 0.00). REY for CP1, CP2 and CP3 were 13.25, 24.46 and $27.75 \mathrm{t} \mathrm{ha}^{-1}$ at Gazipur. The equivalent yields were $14.03,29.48$ and $36.98 \mathrm{t} \mathrm{ha}^{-1}$, respectively, at Kapasia. The highest REY was in 2005 at Gazipur. At Kapasia, the highest REY was observed in 2004. The REY produced by CP3 was the highest and that in CP1 was the lowest for both the locations in each year (Table 12). Khatun et al. (2003) also reported that inclusion of potato in wet-dry transition period between T. Aman and Boro increased the REY of T. Aman- Boro- Fallow cropping pattern.

Total variable costs for $\mathrm{CP} 1, \mathrm{CP} 2$ and $\mathrm{CP} 3$ were US\$ 533, 936 and 978 per hectare, respectively. The high cost of CP3 was incurred from the extra labour required for transplanting to the intermediate field, uprooting of the young plants and preparing them for second transplanting. The additional labour in DT elevated the cost by about US\$41 per hectare, but the return outstripped the additional cost through increased yield of potato and Boro rice. The CP3 gave gross margin of US\$1797 at Gazipur and US\$2720 at Kapasia compared to US\$792 and US\$870 in CP1, and US\$1510 and US\$2012 in $\mathrm{CP} 2$, respectively. The gross margins of CP3 were 127 and $19 \%$ higher at Gazipur and 212 and $35 \%$ higher at Kapasia over CP1 and CP2, respectively (Table 13).

Table 10. Days to maturity in Boro rice (BRRI dhan29) in three seasons at two locations under three cropping patterns.

\begin{tabular}{lllllllll}
\hline $\begin{array}{l}\text { Cropping } \\
\text { pattern }\end{array}$ & \multicolumn{3}{c}{ Gazipur } & & \multicolumn{3}{c}{ Kapasia } \\
\cline { 2 - 9 } & 2004 & 2005 & 2006 & Mean for CP & 2004 & 2005 & 2006 & Mean for CP \\
\hline A-F-B & 162 & 157 & 155 & 158 & 164 & 163 & 157 & 161 \\
A-P-B & 172 & 171 & 166 & 170 & 173 & 175 & 173 & 174 \\
A-P-DB & 171 & 166 & 159 & 165 & 173 & 168 & 166 & 169 \\
Mean for year & 168 & 165 & 160 & 164 & 170 & 169 & 165 & 168 \\
\hline
\end{tabular}

$\operatorname{LSD}_{(0.05)} 0.82$ (for cropping pattern, CP), 0.67 (Location), 0.82(Year), 1.42 (CP x Year), 1.16 (Location x Year), NS (CP x Location), 2.01 (CP x Location $x$ Year) 
Table 11. Rice equivalent yield (REY) (t/ha) of different cropping patterns in three seasons at two locations

\begin{tabular}{lcccccccc}
\hline \multirow{2}{*}{$\begin{array}{c}\text { Cropping } \\
\text { pattern }\end{array}$} & 2004 & 2005 & 2006 & Mean for CP & 2004 & 2005 & 2006 & $\begin{array}{c}\text { Mean for } \\
\text { CP }\end{array}$ \\
\cline { 2 - 9 } & 14.46 & 11.94 & 13.35 & 13.25 & 14.41 & 13.18 & 14.50 & 14.03 \\
\hline A-F-B & 21.47 & 29.54 & 22.38 & 24.46 & 33.96 & 27.89 & 26.58 & 29.48 \\
A-P-B & 25.31 & 30.95 & 27.00 & 27.75 & 38.37 & 35.90 & 36.66 & 36.98 \\
A-P-DB & 20.41 & 24.14 & 20.91 & 21.82 & 28.91 & 25.66 & 25.91 & 26.83 \\
Mean for year & & & & \multicolumn{3}{c}{ Gazipur } \\
\hline
\end{tabular}

$\mathrm{LSD}_{(0.05)} 1.16$ (for cropping pattern, CP), 0.95 (Location ), 1.16 (Year), 2.01 (CP x Year), 1.65 (Location x Year), 1.65 (Location x CP), 2.85 (CP x Location $\times$ Year)

Table 12. Profitability level of different cropping patterns in three seasons at two locations

\begin{tabular}{lllllll}
\hline $\begin{array}{l}\text { Cropping } \\
\text { pattern }\end{array}$ & \multicolumn{3}{c}{ Gazipur } & \multicolumn{3}{c}{ Kapasia } \\
& $\begin{array}{llllll}\text { Total variable } \\
\text { cost (Tk./ha) }\end{array}$ & $\begin{array}{l}\text { Gross } \\
\text { return } \\
\text { (Tk./ha) }\end{array}$ & $\begin{array}{l}\text { Gross margin } \\
\text { (Tk./ha) }\end{array}$ & $\begin{array}{l}\text { Total } \\
\text { variable cost } \\
\text { (Tk./ha) }\end{array}$ & $\begin{array}{l}\text { Gross } \\
\text { return } \\
\text { (Tk./ha) }\end{array}$ & $\begin{array}{l}\text { Gross } \\
\text { margin } \\
\text { (Tk./ha) }\end{array}$ \\
\hline CP1 & 37,338 & 92,570 & 55,412 & 37,338 & 98,210 & 60,872 \\
CP2 & 65,521 & $1,71,220$ & $1,05,699$ & 65,521 & $2,06,360$ & $1,40,839$ \\
CP3 & 68,460 & $1,94,250$ & $1,25,790$ & 68,460 & $2,58,860$ & $1,90,400$ \\
\hline
\end{tabular}

\section{Conclusions}

Double transplanting of Boro was found to be an effective crop establishment method for accommodating a potato crop in between two rice crops in medium high land provided there was irrigation facility. The method was found profitable and thus, it may be a good option for higher return for marginal rice growers in Bangladesh. In medium high land, double transplanting of Boro rice can be practiced as a potential option for optimizing the productivity of CP2. Regardless of locations and years, the highest REY and gross margin were obtained from CP3 followed by CP2. There is scope of substantial improvement of the productivity of the ecosystem with the inclusion of DT in Boro rice.

\section{References}

Choudhury, A.A., Siddique, S.B., Ahmed, K.U., Mannan, M.A., Mazid, M.A., Jabber, M.
A., 1995. Effect of splitted tillers and its effect on grain yield of T. Aman rice. Bangladesh Rice Journal. 6, 59-61.

Choudhury, P.K.D., Guha, B., 2000. Performance of rice varieties under different time of planting in Boro season. Ann. Biol. Ludhi. 16: 41-44.

Elahi, N.E., Khan, A.H., Siddique, M.R., Saha, A., Nasim, M., Mollah, M.I.U., Shahidullah, S.M., 2001. Existing cropping patterns of Bangladesh. Potential technologies and strategies for improving systems productivity. Proceedings of the Workshop on Modern Rice Cultivation in Bangladesh held on 14-16 Feb. 1999, 107-170.

Gomez, K.A., Gomez. A.A., 1983. Statistical Procedures for Agricultural Research. John Wiley and Sons. New York, 188207. 
Khan, A.H., Rashid, H., Khatun, A., Quddus, M.A., Gomosta, A.R., 2004. Rice Farming System: Improved rice-based cropping systems for different ecosystems. Paper presented at the National Farming Systems Technology Inventory Workshop held at CERDI, Gazipur-1701, July 17-19, 2004.

Khatun, A., Khan, A.H., Elahi, N.E., Rashid, M.H., Kabir, M.H., 2003. Agro-economic productivity of two and three crop systems in the irrigated ecosystem. $J$. Bangladesh Agricultural University Research 1: 1-5.

Mridha, A.J., Nasiruddin, M. Siddique, S. B., 1991. Effect of tiller separation on yield and area covered in rice. In: Abstracts of $16^{\text {th }}$ Bangladesh Sci. Conf. held in 1991. Dhaka, 67.
Rashid, M. H., Khan, M. A. H., Khatun, A., and Quddus, M. A. 2004. Optimizing productivity of T. aman-potato-boro cropping pattern by practicing double transplantation in Boro. Journal Subtrop Agricultural Research Development 2(3): 19-23.

Roy Bardhan, S.K., Saha, N. K., Kadian, M.S., Quirox, R., Hangantileke, S., 2007. Improving the livelihood of farmers by intensifying the rice-potato-rice system through double-transplanting of rice in West Bengal, India. Natural Resources Management Division Working paper. No. 2007-1.

Singh, C. V., Singh, R. K., Chauhan, V. S., 1993. Relative performance of pigeon pea genotypes in sole and rice intercrops systems. International Pigeon pea Newsletter. 17: 19-20. 
